\title{
Fresh Specimen
}

National Cancer Institute

\section{Source}

National Cancer Institute. Fresh Specimen. NCI Thesaurus. Code C84517.

Tissue which has not been exposed to a fixative solution. 